\title{
CHARACTERIZATION OF JULY 17, 2006 TSUNAMIITE AT SOUTH COAST OF WEST JAVA
}

\author{
Hendra Amijaya*,Ngisomuddin, and Akmaluddin \\ Department of Geological Engineering, Gadjah Mada University Indonesia
}

\begin{abstract}
July 17, 2006 tsunami which occurred in Indian Ocean had swept most of the south coast of Java, especially at Pangandaran area, West Java. The tsunami wave transported and deposited sediment known as tsunamiite, with various compositions. Three different textural characteristics have been recognized on the tsunami sediment deposit. First type is on the tsunamiite found at West Pangandaran Beach, which is darker than the older beach sediment and separated by erosional surface. The sedimentary structures are parallel lamination and current ripple. The grains have no fining trend in vertical as well as lateral direction. Whereas the second type is found at East Pangandaran Beach, which is brighter than the older beach sediment and also separated by erosional surface. The sedimentary structures are cross lamination on the lower layer, parallel lamination on the middle layer and massif on the upper layer. The grains have no fining trend in vertical and lateral direction Benthic foraminifera is one of organism which is transported and deposited as tsunami deposit on the coast. Ammonia beccarii, Elphidium advenum, Amphistegina lessonii, Cibicides sp., Biginerina irregularis, Bolivina plicata, Bathysiphon sp., Nodosaria and Quinqueloculina were found in the recent tsunami deposit from Pangandaran. Based on the benthic foraminifera contents, it can be inferred that the sediments came from lagoonal until deep sea (abyssal) environment.
\end{abstract}

Keywords: tsunamiite, sediment, benthic foraminifera, Pangandaran

\section{Introduction}

On July 17, 2006, the south coast of West and Central Java, especially at Pangandaran area, Ciamis, West Java have been subjected to tsunami wave which was caused by an earthquake with the magnitude of 6.8 Richter scale. The earthquake happened at

*Corresponding author: H. AMIJAYA, Department of Geological Engineering, Faculty of Engineering, Gadjah Mada University, Jl. Grafika 2 Yogyakarta, 55281, Indonesia. E-mail: amijaya@gmail.com
3:19:28 PM at the south of Pangandaran, and according to Indonesian Meteorological and Geophysical Agency (BMG), the epicenter of this earthquake was located at $9.46^{\circ} \mathrm{S}, 107.19^{\circ} \mathrm{E}$ at the depth of $33 \mathrm{~km}$.

Tsunami wave usually transports marine sediment landward and deposits it onshore. Sediment which is the product of tsunami activity is called tsunamiite. The term tsunamiite is adopted formally by Shiki et al. (2000) and this term was used for the first time in the publication by Gong (1988) (see Shanmugam, 2006).

For the determination of tsunami sediment characteristics, key parameters that should be considered are coast (or beach) morphology, run-up height and distance, deposit thickness, sedimentary structure and grain size and distribution of tsunami sediment (see Bahlburg and Weiss, 2005).

Benthic foraminifera is one of the organism that can be found in the tsunami deposit. Teoritically, tsunami sediment comes from seabed or coastal areas which are subjected to tsunami. Benthic foraminifera adapt only in a certain environment, therefore this organism is a good indicator of depositional environment. Using this characteristic, foraminifera which found in the tsunami deposit can be used to determine the environment and depth of the area where the deposit was orinigated (Bahlburg and Weiss, 2005). This research was done to characterize the textural appearance and the benthic foraminifera content of tsunami sediment taken from South coast of West Java especially Pangandaran Beach, Ciamis.

\section{Methodology}

The sediment samples were taken from three location, which are West Pangandaran Beach (Jonggormanggu-Karangsimpang village) and East Pangandaran Beach (Dusun Kelapa-Karangsari village), both are located in Ciamis (West Java, see Figure 1). Data collection was conducted by making a profile across the beach from the maximum tide 


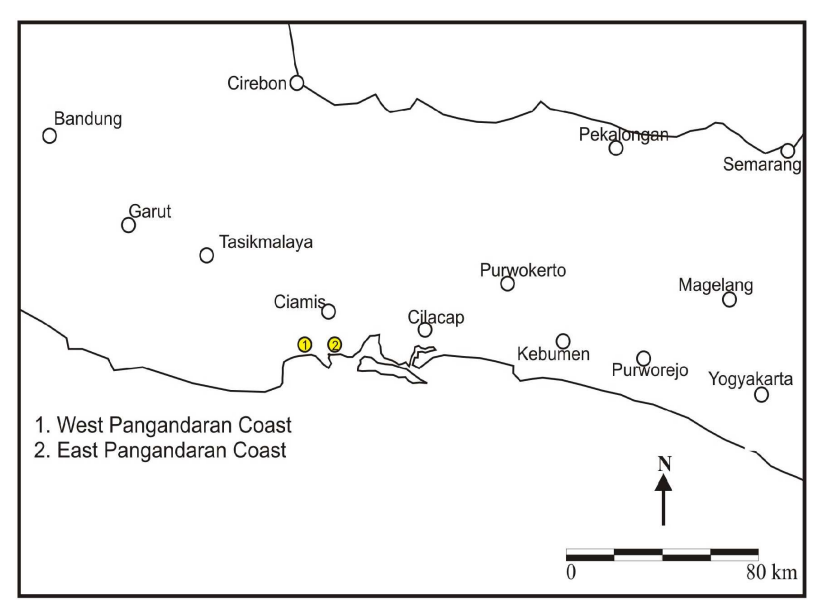

Figure 1: Research locations.

point to the maximum tsunami run-up. Some holes were made (depth $0.5-1 \mathrm{~m}$ ) along the profile until the border of old beach sediment and tsunami sediment was found.

Physical appearances of sediment like thickness and structure could be observed directly on the field. On each holes tsunamiite samples were taken from each layer distinguished by the differences of physical appearances especially sedimentary structure and color. For textural identification, granulometry analysis was then used. Sieving was conducted by using mechanical sieve with mesh 35 (Ø $0.5 \mathrm{~mm})$, mesh 60 (Ø $0.25 \mathrm{~mm})$, mesh $115(\varnothing 0.124 \mathrm{~mm})$, mesh $230(\varnothing 0.063 \mathrm{~mm})$, mesh $270(\varnothing 0.053 \mathrm{~mm})$ and mesh $<270(\varnothing<0.053 \mathrm{~mm})$. Mean, sortation, skewness and kurtosis were calculated using mathematical method and classified based on Folk and Ward (1957).

Sediment sample preparation was relatively not needed for foraminifera observation because the sediment are already clean and mostly have sand in grain size so that the sediment can be directly observed under microscope. Benthic foraminifera identification and environment determination was based on Bandy (1967).

\section{Results and discussions}

West Pangandaran. Morphologically, West Pangandaran Beach has a flat topography. This condition caused that tsunami wave could move easily onshore and reached Cikembulan River, around 750 $\mathrm{m}$ landward from the beach. The height of the wave was approximately $3 \mathrm{~m}$.

Typical tsunami sediment was found $3 \mathrm{~m}$ from maximum tide point. The tsunamiite is only $10 \mathrm{~cm}$ thick and an erosional surface borders it with old beach sediment. Beside that, the tsunami sediment has darker color than old beach sediment. Basically this sediment can be divided into 3 layers. The lowermost and middle layers are characterized by parallel lamination structure, as the uppermost layer is characterized by ripple structure. The ripple structure shows a landward direction as a manifestation of tsunami run-up movement (see Figure 2).

The mean grain size of tsunami deposit is between medium sand and fine sand. Vertically the deposit is relatively homogene and shows no fining upward appearance. The skewness has positive value (strongly fine skewed) which means that the finer grain size is more than the coarser grain size. The sortation is also almost the same for all layers, which is moderately well sorted. Kurtosis value varied between extremely leptokurtic to very leptokurtic.

The benthic foraminifera which were found in all three layers were same. Those are Ammonia beccarii, which lives in lagoonal condition, Elphidium advenum and Amphistegina lessonii from inner neritic environment. Depth of inner neritic environment is about $0-100$ feet $(0-30 \mathrm{~m})$. Other benthic foraminifera in this deposit are Cibicides sp. and Biginerina irregularis which live in middle neritic environment (100-300 feet, or 30-90 m). Beside that, foraminifera from deeper depth such as Nodosaria (lower-upper bathyal, 600-6000 feet or about 180-1820 m) and Bolivina plicata from upper bathyal were found. Interesting thing is that benthic foraminifera from abyssal environment (more than 6000 feet), Bathysiphon sp., was also observed (Figure 4).

In the lowermost layer, foraminifera from lagoonal environment is dominant. This could be caused as the tsunami wave eroded coastal area (including lagoon) so that the sediment from this area were brought by the tsunami. However, in general, the benthic foraminifera is mostly dominated by foraminifera from inner neritic environment. This indicates that the sediment brought by tsunami was mostly came from inner neritic environment. The location of earthquake epicenter which close to the Pangandaran had caused the occurrence of benthic foraminifera from abyssal environment since the energy of tsunami wave was high enough to transport sediment from deep marine environment to the beach. This process is also supported by the fact that the seabed is extremely deeping and has a very step morphology near the beach.

East Pangandaran. East Pangandaran Beach has a relatively same morphological feature with West Pangandaran Beach, but the tsunami wave run-up only reach $300 \mathrm{~m}$ landward and the height is only around $1.4 \mathrm{~m}$, since the East Pangandaran Beach is protected by the small cape at the east of it. This barrier reduced the tsunami wave energy. 

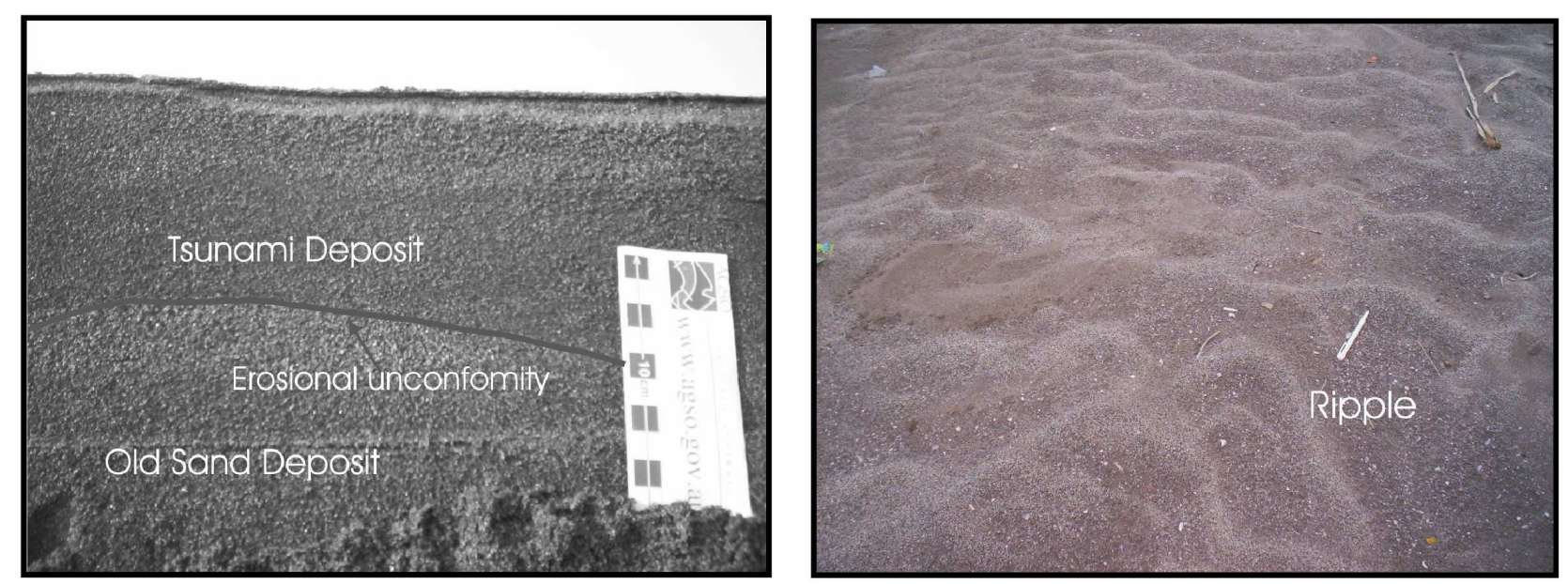

Figure 2: Photographs of tsunamiite at West Pangandaran Beach.

Obvious tsunami deposit was found $10 \mathrm{~m}$ from the highest tide point with the thickness of $12.2 \mathrm{~cm}$. To the land direction, the tsunamiite is thinner. As in West Pangandaran, the tsunamiite and the old beach sediment is separated by erosional surface. The deposit consists of 3 layers. The lowermost layer has cross lamination structure with landward direction which indicates run-up wave direction. Above this layer, parallel lamination structure is found. The uppermost layer is characterized by massive layer (see Figure 3).

In this beach, the mean grain size of tsunami deposit is between medium sand and fine sand, which is the same with the West Pangandaran tsunami sediment. Vertically, the deposit also shows no fining upward appearance. However, the skewness vary from coarse skewed to fine skewed. The sortation is moderately well sorted. Kurtosis value also varies between extremely leptokurtic to very leptokurtic.

The benthic foraminifera observed in those layers are relatively same. Those are Ammonia beccarii from lagoonal environment, Elphidium advenum, Quinqueloculina tenagos, and Amphistegina lessonii which indicate outer neritic environment. Other foraminifera from neritic environment found in this sample are Cibicides sp. and Biginerina irregularis (middle neritic). Benthic foraminifera from deeper environment in this sample are Bolivina plicata from upper bathyal (600-1500 feet, approx. 180-460 m) and Bathysiphon sp. (abyssal). Photos of those foraminifera are shown in Figure 4.

Basically the distribution of benthic foraminifera in this location has a same characteristic with the West Pangandaran area. This fact shows that transportation and deposition of sediment by tsunami deposit in East Pangandaran were occurring in the same manner with the process occurred in West Pangandaran, respectively.

\section{Conclusions}

The characteristic of tsunami deposit are typical for each location. The differences are caused by the local configuration of tsunami process which depends on some factors such as submarine and coast (beach) morphology. However, at all locations, an erosional surface can be found between the tsunamiite and old beach sediment. The deposit is relatively homogene in grain size and has no fining upward trend. The sortation is usually moderately well sorted. Skewness and kurtosis can vary at each location.

At West Pangandaran Beach, the sedimentary structures of tsunami deposit are parallel lamination and ripple. The deposit is medium to fine sand in grain size. Variation of sedimentary structure is obvious at East Pangandaran Beach. The layers of tsunami sediment (medium to fine sand) show cross lamination, parallel lamination and massive structure.

Benthic foraminifera found in West and East Pangandaran July 17, 2006 tsunami deposit are Ammonia beccarii, Elphidium advenum, Amphistegina lessonii, Cibicides sp., Biginerina irregularis, Bolivina plicata, Bathysiphon sp. Nodosaria was observed in the sample from West Pangandaran, whereas Quinqueloculina was found in sample rom East Pangandaran. Those facts are indication that the tsunami sediment was originally from various environment (lagoon until abyssal). The distance of each beach to the earthquake epicenter and the seabed morphology will affect the source of sediment which is transported and deposited by tsunami. 

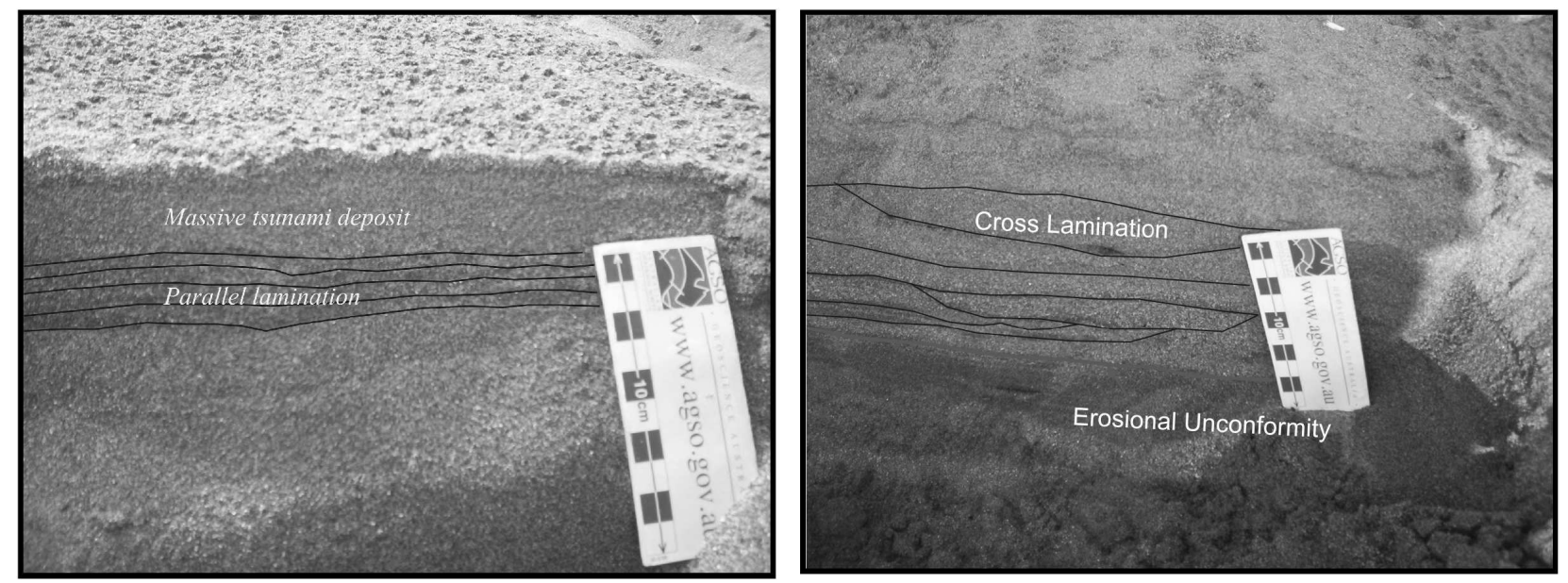

Figure 3: Photographs of tsunamiite at East Pangandaran Beach.

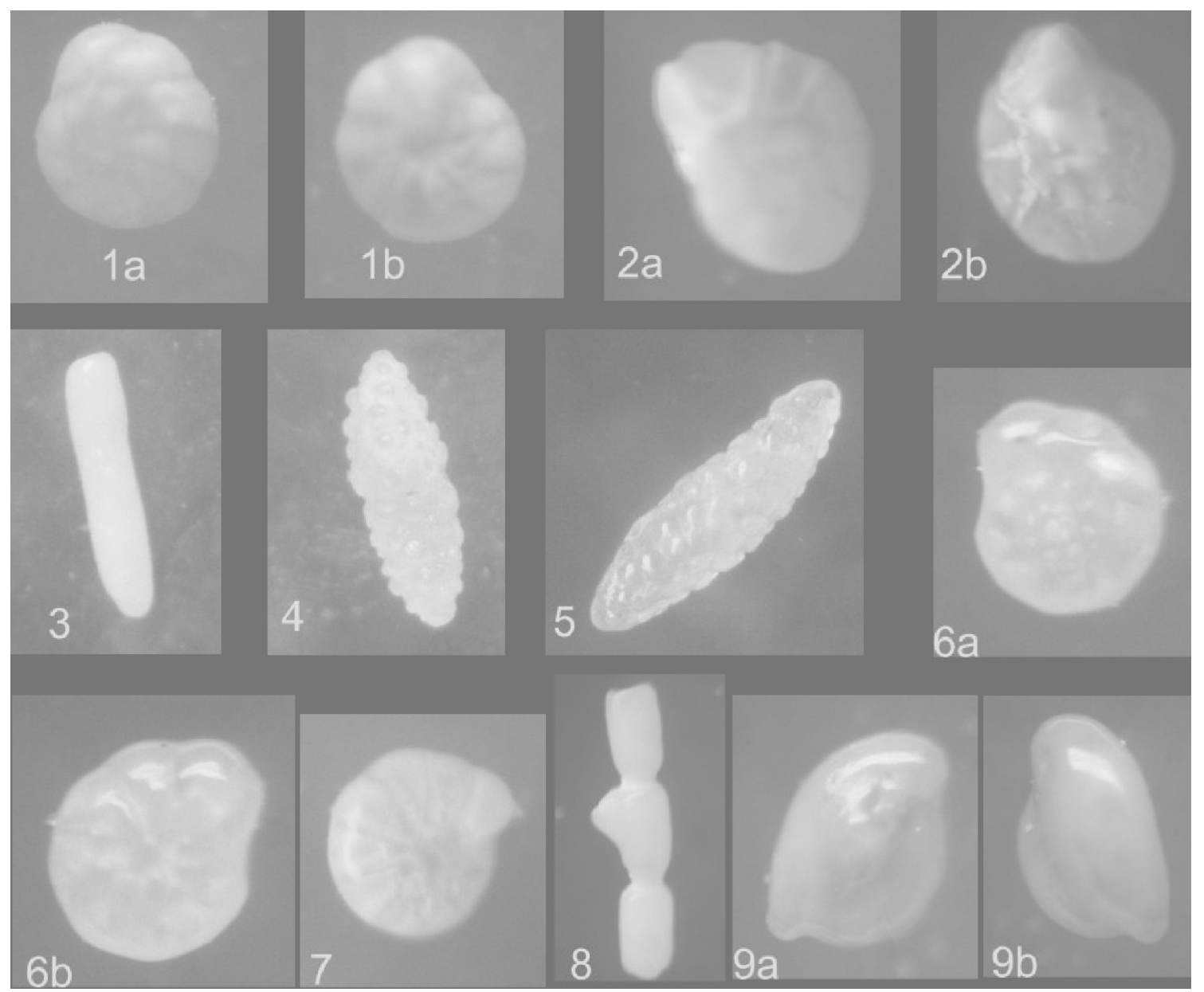

Figure 4: Photographs of some benthic foraminifera found. 1. Ammonia beccarii (a. Dorsal, b. Ventral), 2. Amphistegina lessonii (a. Dorsal, b. Ventral), 3. Bathysipon sp., 4. Biginerina irregularis, 5. Bolivina plicata, 6. Cibicides sp. (a. Dorsal, b. Ventral), 7. Elphidium advenum, 8. Nodosaria sp., 9. Quinqueloculina tenagos (a. Dorsal, b. Ventral). 


\section{References}

Bahlburg, H., Weiss, R. (2006) Sedimentology of the December 26, 2004, Sumatera Tsunami Deposit in Eastern India (Tamil Nadu) and Kenya. International Journal of Earth Sciences 93(2): 207-223.

Bandy, O. L. (1967) Foraminiferal indicies in paleoecology. Esso Production Research Company, Houston, Texas, 77 p.
Folk, R. L. and Ward, W.C. (1957) Brazor river bar: A study in the significance of grain Size parametres. Journal of Sedimentary Petrology 27: 3-26.

Shanmugam, G. (2006) The Tsunamiite problem. Journal of Sedimentary Research 76(5-6): 718-730. 